\title{
Tatakelola Keuangan UMKM Berbasis ETAP dan Android Untuk Meningkatkan Efisiensi Kinerja Usaha pada Era Covid-19 Normal Baru
}

\author{
Sailendra ${ }^{1}$, Syahril Djaddang ${ }^{2}$, M. Ardiansyah Syam ${ }^{3}$, Susilawati ${ }^{4}$, Nungki P $^{5}$ \\ 1,2,3 Sekolah Pascasarjana Universitas Pancasila, Jakarta, Indonesia \\ ${ }^{4}$ Fakultas Ekonomi dan Bisnis, Universitas Pancasila, Jakarta, Indonesia \\ ${ }^{5}$ Fakuktas Pariwisata, Universitas Pancasila, Jakarta, Indonesia \\ *E-mail:syahril@univpancasila.ac.id
}

\begin{abstract}
Abstrak
Usaha Mikro Kecil dan Menengah (UMKM) dan Koperasi, merupakan salah satu pilar serta tulang punggung perekonomian bangsa, yang menyerap banyak tenaga kerja dan kesempatan berusaha pada sektor informal.Pandemi Covid-19 dan disrupsi industri 4.0 telah merubah tatanan sosial-ekonomi, turut mempengaruhi jenis industri ini. Salah satu tantangan yang dihadapi oleh UMKM dan Koperasi saat ini, masih rendahnya literasi akuntansi dan tatakelola keuangan, ditambah dengan transformasi tatanan sosial-ekonomi dari sistem konvensional ke sistem digital. Salah satu solusi untuk meningkatkan pengetahuan UMKM dan Koperasi terhadap dunia digital yang berhubungan dengan literasi akuntansi dan tatakelola keuangan yaitu melalui pelatihan, pendampingan dan penelitian. Pelatihan, pendampingan dan penelitian terhadap para pelaku UMKM dan Koperasi ini dilakukan dengan metode berinteraksi langsung melalui tatap muka dan observasi lapangan. Implikasi dari hasil pelatihan, pendampingan dan penelitian, merekomendasikan agar pelatihan dan pendampingan yang dilakukan oleh akademisi bersinergi dengan Dinas Koperasi dan UMKM, perlu terus dilakukan secara berkesinambungan. Karena, dengan pelatihan dan pendampingan yang berkesinambungan, literasi dan keterampilan akuntansi berbasis SAK ETAP dan tatakelola keuangan berbasis teknologi digital Android UMKM dapat ditingkatkan. Sehingga efisiensi dan kinerja usaha dapat tercapai. Terutama pada era pandemi Covid-19 dan normal baru, agar pelaku usaha UMKM tetap dapat eksis dan mampu berkompetisi dalam menghadapi persaingan usaha.
\end{abstract}

Kata Kunci: umkm dan koperasi, efisiensi dan kinerja usaha, akuntansi berbasis android, digitalisasi takakelola keuangan, covid-19, normal baru.

\begin{abstract}
Micro Small and Medium Enterprises (MSMEs) and Cooperatives are one of the pillars and backbone of the nation's economy, which absorbs a lot of labor and business opportunities in the informal sector. The Covid-19 pandemic and industrial disruption 4.0 have changed the socio-economic order; it also affects this type of industry. One of the challenges faced by MSMEs and Cooperatives today is
\end{abstract}


the low accounting literacy and financial governance, coupled with the transformation of the socio-economic order from conventional to digital systems. One solution to increase the skill and knowledge of MSMEs and Cooperatives to the digital system related to accounting literacyand financial governance is through training, mentoring, and research. Pieces of training, mentoring, and research on MSMEs and Cooperative members are conducted by interacting directly through face-to-face and field observation. The implications of the results of this training, mentoring and study, recommend that the training and mentoring undertaken by academics in synergy with Cooperatives and MSMEs Government need to continue to be carried out on an ongoing basis. With continuous training and mentoring, literacy, and accounting skills based on SAK ETAP andfinancial governance based on Android, MSMEs can be improved to achieve the business's efficiency and performance. Especially in the era of the Covid-19 pandemic and the new normal, MSMEs are still available to exist and compete in the business competition.

Keywords: msmes and cooperative, efficiency and business performance, android-based accounting, digitization of financial governance, covid-19, new normal.

\section{PENDAHULUAN}

Koperasi serta Usaha Mikro Kecil dan Menengah (UMKM) merupakan salah satu pilar perekonomian bangsa. Dalam dua dekade ini, kelompok usaha Koperasi dan UMKM tersebut merupakan salah satu jenis kelompok usaha yang berkontribusi besar dalam menopang perekonomian negara, terutama dalam menyerap tenaga kerja dan membuka lapangan kerja, khususnya tenaga kerja dan lapangan kerja di sektor informal (Sailendra, Suratno, \& Tampubolon, 2020). Begitupula peran dan fungsinya sebagai penopang perekonomian negara, jenis usaha mikro dan kecil ini tetap dapat eksis dalam menjalankan usahanya, walaupun krisis ekonomi melanda, yang mengakibatkan banyak perusahaan besar dan sektor formal berjatuhan akibat dari adanya krisis ekonomi. Sehingga banyak perusahaan besar dan formal tersebut harus menutup aktifitas usahanya dengan berbagai alasan, karena tidak dapat bertahan dari terjangan badai krisis ekonomi. Pengalaman mengajarkan, ditengah krisis ekonomi Indonesia, usaha UMKM justru malah berperan menjadi tulang punggung ekonomi negara (PikiranRakyat.com, 2021b).

Semenjak kasus pandemi Covid-19 pertama kali ditemukan di kota Wuhan China pada 1 Desember 2019 (CnnIndonesia.com, 2020), yang kemudian menyebar keseluruh dunia, tidak terkecuali, Indonesia. Di Indonesia, kasus pandemi Covid-19 pertama kali ditemukan menginfeksi dua warga negara Indonesia pada tanggal 2 Maret 2020, sebagaimana di umumkan secara resmi oleh pemerintah (Kompas.com, 2020). Semenjak ditemukannya kasus pertama yang menginfeksi dua warga negara Indonesia tersebut, kemudian pandemi Covid-19 menyebar ke seluruh pelosok Indonesia. Menjalarnya penyebaran Covid-19 keseluruh pelosok Indonesia tersebut, menyebabkan pemerintah membuat kebijakan guna memutus mata rantai penularan dengan menerapkan protocol kesehatan yang cukup ketat, yaitu salah satunya menerapkan Pembatasan Sosial Berskala Besar (PSBB) dengan membatasi kegiatan dan interaksi masyarakat, termasuk melakukan pembatasan jarak, interaksi dan aktifitas. Sehingga mengurangi pergerakan orang dan barang yang sangat signifikan. 
Implikasi dari penerapan protokol kesehatan yang ketat tersebut, ternyata berdampak negatif terhadap kehidupan sosial serta ekonomi masyarakat, terutama sektor produksi dan distribusi. Dampak negatif sosial ekonomi dari PSBB karena pandemi Covid-19 tersebut, juga sangat memukul usaha kelompok industri mikro kecil dan menengah (UMKM) dan Koperasi. Sehingga berdasarkan survey yang dilakukan oleh ADB pada bulan September 2020 sebanyak 48,6 persen usaha UMKM di Indonesia tutup sementara dan penurunan permintaan domestik sebesar 30,5 persen (Antaranews.com, 2020b). Tak hanya itu, UMKM di Indonesia, mengalami permasalahan lain akibat dari pandemi, yaitu sulit mendapatkan bahan baku dan terhambatnya distribusi karena logistik yang tersendat akibat dari terbatasnya pergerakan orang dan barang. Hal tersebut berdampak terhadap turunnya permintaan in line dengan banyaknya pemutusan hubungan kerja (PHK) sehingga sangat berpengaruh terhadap omset dan pendapatan pelaku UMKM dan Koperasi, sehingga berdampak terhadap turunnya pendapatan dan daya beli masyarakat.

Namun demikian, walaupun dampak dari pengaruh pandemi covid-19 telah melemahkan kondisi perekonomian Indonesia secara umum, saat ini, sebagian besar UMKM yang ada masih tetap dapat eksis dan bertahan (Antaranews.com, 2020a) berkat kebijakan yang diberikan oleh pemerintah melalui bantuan UMKM, relaksasi pembayaran bunga kredit, dan akibat dari bertransformasinya para pelaku usaha dari sistem tradisional ke sistem digital, baik pemasaran, pola transaksi dan tatakelola keuangan yang dilakukan oleh pelaku usaha UMKM.

Tabel 1.1. Jumlah Usaha Mikro Kecil dan Menengah Menurut Kecamatan dan Bidang Usaha di Kota Bogor, Tahun 2019

\begin{tabular}{|l|r|r|r|r|r|r|}
\hline \multirow{2}{*}{ Kecamatan } & \multicolumn{7}{|c|}{ Bidang Usaha } \\
\cline { 2 - 7 } & Kuliner & Pakaian & Pendidikan & Otomotif & Agrobisnis & $\begin{array}{r}\text { Jaringan } \\
\text { Internet }\end{array}$ \\
\hline \multicolumn{1}{|c|}{$(1)$} & $(2)$ & $(4)$ & $(5)$ & $(6)$ & $(7)$ \\
\hline $\begin{array}{l}\text { 010 Bogor } \\
\text { Selatan }\end{array}$ & 1.239 & 571 & 344 & 346 & 335 & 270 \\
\hline 020 Bogor Timur & 824 & 368 & 224 & 219 & 224 & 186 \\
\hline 030 Bogor Utara & 3.241 & 1.473 & 870 & 875 & 867 & 743 \\
\hline $\begin{array}{l}\text { 040 Bogor } \\
\text { Tengah }\end{array}$ & 2.007 & 902 & 554 & 543 & 552 & 440 \\
\hline 050 Bogor Barat & 1.220 & 533 & 330 & 318 & 334 & 272 \\
\hline 060 Tanah Sereal & 983 & 465 & 274 & 284 & 258 & $\mathbf{2 . 1 2 9}$ \\
\hline Kota Bogor & $\mathbf{9 . 5 1 4}$ & $\mathbf{4 . 3 1 2}$ & $\mathbf{5 . 5 9 6}$ & $\mathbf{2 . 5 8 5}$ & $\mathbf{2 . 5 7 0}$ & \\
\hline
\end{tabular}

Sumber: BPS Kota Bogor, 2020

Kabupaten Bogor, merupakan salah satu sentra UMKM dan Koperasi, terutama UMKM Kuliner dan rekreasi, sebagai salah satu tujuan destinasi wisata lokal bagi masyarakat sekitarnya. Terutama penduduk dan masyarakat Jakarta, Depok, Tangerang, Bekasi dan wilayah lain yang berdekatan. Dikarenakan secara Kota Bogor memiliki jarak yang relatif dekat secara demografis. 
Sedangkan secara historis penduduk disekitarnya memiliki Ikatan sosial dan kultural yang erat dengan wilayah Kabupaten dan Kota Bogor. Namun demikian, penerapan protokol kesehatan yang lebih ketat untuk melakukan aktifitas perjalanan, serta pemangkasan hari libur di akhir tahun membuat banyak konsumen membatalkan rencana perjalanan wisata dan belanjanya. Hal ini menyebabkan banyak usaha perhotelan, transportasi dan perdagangan mengalami penurunan pendapatan (PikiranRakyat.com, 2021a).

Pertumbuhan UMKM di Kota Bogor, cukup berkembang secara signifikan dari tahun ke tahun, terutama UMKM yang bergerak pada bidang kuliner, hampir tersebar diseluruh wilayah Bogor secara merata. Usaha kuliner merupakan jumlah industri UMKM yang paling tinggi di Kota Bogor, kemudian disusul oleh industri pakaian (konveksi), pendidikan, otomotif, agrobisnis dan jaringan internet. Namun demikian, akibat dari pandemi Covid-19, banyak sektor usaha yang terdampak, tak terkecuali usaha UMKM menjadi menurun (Antaranews.com, 2020b).

Semenjak adanya pandemi Covid-19, kondisi wirausaha Koperasi dan UMKM di Kota Bogor saat ini sedang mengalami stagnan. Selain kebijakan dan bantuan dari pemerintah berupa modal kerja dan relaksasi bunga kredit, guna mendorong agar pelaku UMKM dapat bertahan dan eksis dalam menghadapi krisis yang diakibatkan oleh pandemi. Guna mendorong agar pelaku usaha UMKM dapat tetap eksis, dan bertumbuh. Pemerintah Kota Bogor, melalui Dinas terkait, melakukan program stimulus, seperti bantuan perizinan usaha, pelatihan keterampilan, bantuan kemudahan modal, serta dukungan pemasaran, agar dapat membantu pelaku UMKM untuk tetap eksis dan berkembang (Antaranews.com, 2020a). Salah satu dukungan strategis tersebut, Dinas Koperasi Kota Bogor bersinergi dengan Akademisi menyelenggarakan pembinaan dan pelatihan tentang kewirausahaan serta membuat laporan keuangan berbasis PSAK ETAP dan android, guna meningkatkan efisiensi dan tatakelola keuangan UMKM.

Tabel 1.2. Jumlah Koperasi Aktif Menurut Kecamatan dan Bidang Usaha di Kota Bogor, Tahun 2019

\begin{tabular}{|l|r|r|r|r|}
\hline \multirow{2}{*}{ Kecamatan } & \multicolumn{5}{|c|}{ Bidang Usaha } \\
\cline { 2 - 6 } & Produksi & Konsumsi & Simpan Pinjam & Serba Usaha \\
\hline (1) & $(2)$ & $(3)$ & $(4)$ & $(5)$ \\
\hline 010 Bogor Selatan & 4 & 61 & 8 & 2 \\
\hline 020 Bogor Timur & 0 & 38 & 8 & 8 \\
\hline 030 Bogor Utara & 1 & 54 & 5 & 3 \\
\hline 040 Bogor Tengah & 1 & 123 & 10 & 10 \\
\hline 050 Bogor Barat & 2 & 77 & 12 & 11 \\
\hline 060 Tanah Sereal & 2 & 83 & 8 & $\mathbf{4 3}$ \\
\hline Kota Bogor & $\mathbf{1 0}$ & $\mathbf{4 3 6}$ & $\mathbf{5 1}$ & 9 \\
\hline
\end{tabular}

Sumber. BPS Kota Bogor, 2020

Masih rendahnya literasi akuntansi dan tatakelola keuangan berbasis PSAK ETAP yang dimiliki oleh pelaku usaha UMKM kota Bogor, serta pengetahuan penguasaan teknologi akuntansi keuangan berbasis android juga masih lemah. Menjadikan penelitian dan pelatihan ini sangat penting 
untuk dilakukan. Melalui pelatihan, pendampingan serta penelitian, merupakan salah satu jalan untuk meningkatkan keunggulan yang harus dimiliki oleh pelaku UMKM, agar usaha yang mereka kelola dapat menjadi lebih efisien guna meningkatkan kinerja usaha, sehingga dapat terus bertahan dan eksis, selama pandemi Covid-19 berlangsung dan guna mempersiapkan diri menyongsong masa normal baru, setelah masa pandemi berakhir. Karena dukungan digitalisasi dapat mendorong UMKM agar tetap terus bertahan dan maju, sehingga menjadi penyokong ekonomi negara utamanya di masa pandemi Covid-19 (PikiranRakyat.com, 2021b).

\section{METODE PELAKSANAAN}

Pengabdian pada masyarakat ini dilaksanakan dalam bentuk pelatihan, pendampingan dan penelitian lapangan, dilaksanakan dengan tatap muka, berinteraksi secara langsung dengan pelaku usaha dan observasi lapangan, menggunakan metode penelitan tindakan (action research). Menurut (Syam, Djaddang, Salim, \& Rachbini, 2020) Action research merupakan salah satu cara yang dilakukan dalam melakukan penelitian yang mendeskripsikan, menginterpretasikan dan kemudian dijelaskan oleh peneliti atas situasi yang ada sebagaimana adanya. Metode ini digunakan untuk mendapatkan gambaran secara utuh terhadap permasalahan dan hambatan yang dihadapi oleh para pelaku Koperasi dan UMKM, sehingga dapat dilakukan intervensi dan modifikasi sesuai dengan tujuan guna dilakukan perbaikan. Sehingga, permasalahan dan hambatan yang dihadapi oleh para pelaku usaha Koperasi dan UMKM didapatkan solusinya.

Pelaksanaan pengabdian masyarakat, terhadap pelaku usaha UMKM dan Koperasi, dilaksanakan atas sinergi dari para akademisi (dalam hal ini dilaksanakan oleh Sekolah Pascasarjana Magister Akuntansi Universitas Pancasila, Fakultas Ekonomi dan Bisnis Universitas Pancasila serta Fakultas Pariwisata Universitas Pancasila) bekerjasama dengan Kantor Dinas Koperasi dan UMKM Kabupaten Bogor, meliputi pelatihan, pendampingan dan penelitian terhadap tatakelola keuangan dan penyajian hasil usaha berdasarkan PSAK ETAP berbasis teknologi digital Android, mencakup langkah-langkah pelaksan aan pengabdian sebagai berikut:

a. Metode pendekatan Forum Group Diskusi (FGD) yang dapat diterapkan, seperti: pelatihan pencatatan sesuai PSAK ETAP Koperasi dan UMKM dengan teknologi berbasis Android. Pola pembimbingan, pengawasan terhadap tenant, pola pemberian bantuan teknologi dan metode penyelesaian masalah dengan metode pencatatan PSAK ETAP Koperasi dan UMKM berbasis teknologi digital Android.

b. Kemungkinan adanya kolaborasi dengan Dinas Koperasi dan UMKM. Kolaborasi dengan lembaga profesi Ikatan Akuntan Publik Indonesia dalam hal pelatihan metode pencatatan PSAK ETAP Koperasi dan UMKM berbasis teknologi digital Android.

c. Rencana pengembangan pengabdian kepada masyarakat pada tahun-tahun selanjutnya, dengan pengembangan unit usaha kreatif yang dapat dikoordinir langsung oleh Tim Pengabdian pada Masyarakat, bekerjasama dengan Dinas Koperasi dan UMKM pada empat wilayah dalam menerapkan standar PSAK ETAP Koperasi dan UMKM berbasis teknologi digital Android untuk wilayah wirau saha kreatif Koperasi dan UMKM di Kota Bogor. 
Pengabdian kepada masyarakat ini, dilakukan dalam situasi pandemi virus Covid-19 yang sedang melanda dunia. Namun demikian, dengan menjaga protokol kesehatan yang ketat, acara ini dapat dilakukan secara tatap muka, dengan peserta yang dibatasi sebanyak dua puluh pelaku usaha UKM, dengan melakukan kunjungan ke lokasi tempat pengabdian masyarakat dilaksanakan, di kota Bogor, Jawa Barat. Kegiatan pengabdian kepada masyarakat ini dilaksanakan pada tanggal 26 Agustus 2020. Secara terstruktur, metode pelaksanaan kegiatan pengabdian kepada masyarakat, dilakukan sebagai berikut:

a. Pemaparan materi dengan topik "Standar Akuntansi Koperasi berbasis ETAP dan Standar Akuntansi Keuangan EMKM"

b. Penjelasan mengenai Akuntansi UMKM Serba Usaha berbasis android disertai dengan contoh perhitungan pajaknya.

c. Penjelasan mengenai Aplikasi Akuntansi Koperasi Usaha Serba Ada;

d. Menyebarkan Kuesioner terkait dengan profil peserta, profil usaha, dan kegiatan pelaporan keuangan berbasis ETAP dan Android;

e. Diskusi dan tanya jawab terkait kegiatan pelaporan keuangan berbasis ETAP dan Android;

f. Fokus Group Discussion (FGD) dengan para pelaku Koperasi dan UMKM Kota Bogor

Kegiatan pengabdian kepada masyarakat, pendampingan dan penelitian ini dilakukan dengan metode interaksi dua arah dengan pelaku usaha dan observasi lapangan. Kemudian dilanjutkan dengan penjelasan atas laporan laba rugi untuk Koperasi dan UMKM oleh para nara sumber. Kemudian, pada kesempatan yang sama diberikan waktu untuk melakukan interaksi tanya jawab antara peserta dan narasumber. Hasil dari pengabdian masyarakat ini, merupakan bahan masukan untuk sebagai program penelitian dan pengabdian masyarakat, guna memberikan solusi terhadap masalah yang dihadapi oleh Koperasi dan UMKM pada umumnya, serta masyarakat Kota Bogor, khususnya.

\section{HASIL DAN PEMBAHASAN}

Disrupsi industri 4.0, kemudian disusul dengan terjadinya pandemi Covid-19. Mengakibatkan perubahan secara signifikan terhadap tatanan kehidupan sosial, budaya dan ekonomi masyarakat, dari sistem konvensional menjadi berbasis digital. Transformasi dari sistem konvensional ke sistem digital tersebut, tidak terlepas mempengaruhi sektor industri Koperasi dan UMKM. Tidak terkecuali, sistem tatakelola keuangan dari tradisional bertransformasi menjadi berbasis teknologi digital Android. Dampak transformasi tersebut, secara umum dirasakan dan berpengaruh bagi para pelaku usaha UMKM di Kota Bogor.

Pengabdian pada masyarakat ini, dilaksanakan pada tanggal 26 Agustus 2020. Sedangkan pelatihan, pendampingan dan penelitian ini, dengan mempertimbangkan kemudahan, jarak dan efisiensi di pusatkan di Kantor Dinas Koperasi dan UMKM Kota Bogor. Peserta PKM di ikuti sebanyak dua puluh satu orang, yang berasal dari Kota Bogor, provinsi Jawa Barat. Terdiri dari UMKM dan usaha yang dirintis sendiri yang tersebar di sekitar wilayah Kota Bogor, antara lain dari Bogor Tengah, Bogor Barat, Bogor Timur, Bogor Utara, Bogor Selatan dan sekitarnya. 
Berdasarkan hasil observasi lapangan, yang dilakukan dengan metode wawancara langsung dan pengisian kuesioner oleh peserta pelatihan PKM yang dipandu oleh narasumber dan pendamping, didapat data dan profil peserta pelatihan UMKM Kota Bogor, sebagai berikut:

Tabel 1.3. Statistik Deskriptif Penelitian

\begin{tabular}{|l|c|c|c|c|c|}
\hline \multicolumn{1}{|c|}{ KETERANGAN } & N & Min & Max & Mean & S. Dev \\
\hline Umur & 21 & 22 & 55 & 41 & 9.49 \\
\hline Modal (Juta) & 21 & 5 & 500 & 15 & 115 \\
\hline Omzet (Juta/Thn) & 21 & 5 & 400 & 14 & 97 \\
\hline Keuntungan (Juta/Thn) & 21 & 5 & 100 & 13 & 30 \\
\hline SAK ETAP & 21 & 0 & 0 & 0 & 0 \\
\hline Android & 21 & 0 & 0 & 0 & 0 \\
\hline
\end{tabular}

Sumber: Diolah untuk penelitian ini(2021)

Keterangan: Umur = Umur peserta dalam tahun; Modal = Jumlah modal usaha dalam rupiah; Omzet = rata-rata jumlah omzet per-tahun dalam rupiah; Keuntungan $=$ Jumlah rata-rata keuntungan pertahun dalam rupiah; SAK ETAP = Jumlah pelaku usaha yang telah melaksanakan pembukuan berbasis SAK ETAP; Android = Jumlah pelaku usaha yang telah melakukan pembukuan berbasis digital-android.

Pelatihan PKM, di ikuti langsung oleh pimpinan atau pemilik usaha UMKM. Dari dua puluh satu peserta yang hadir terdiri dari $98 \%$ peserta wanita dan $2 \%$ merupakan pelaku usaha UMKM berjenis kelamin pria. Jumlah peserta yang hadir untuk periode ini, sengaja dibatasi, karena pelatihan diadakan pada saat masih berlangsungnya pandemi Covid-19 dengan menjalankan protokol kesehatan yang ketat.

Umur pelaku usaha UMKM yang mengikuti pelatihan, dengan rentang usia antara 22 tahun sampai dengan 55 tahun, namun demikian sebagian besar pelaku usaha UMKM yang mengikuti pelatihan rata-rata berumur 41 tahun. Sedangkan tingkat pendidikan pelaku usaha UMKM, terendah adalah Sekolah Menengah Atas (SMA) sederajat, namun demikian terdapat pengusaha UMKM yang memiliki tingkat pendidikan Diploma Tiga, Strata Satu bahkan Strata Dua. Berdasarkan data yang ada, pelaku u saha UMKM di Kota Bogor dikelola oleh pemilik yang memiliki usia yang produktif, hal ini membuktikan bahwa, jenis usaha UMKM menyerap tenaga kerja di sektor informal, sebagaimana dibuktikan secara empiris dari berbagai hasil penelitian yang ada. Sedangkan tingkat pendidikan pelaku usaha UMKM dengan pendidikan paling rendah dengan tingkat sekolah menengah atas sederajat, bahkan terdapat pelaku usaha dengan pendidikan Diploma, Strata Satu bahkan Strata Dua, juga membuktikan bahwa, sektor industri UMKM, merupakan jenis pekerjaan yang layak dipertimbangkan dengan penghasilan dan memiliki masa depan yang menjanjikan, sebagai alternatif pilihan profesi atau pekerjaan. Karena sangat terbatas ketersediaan lapangan pekerjaan di sektor formal yang dapat disediakan oleh pemerintah, menjadi pengu saha dan pemilik UMKM menjadi solusi, untuk mengatasi dan menyerap lonjakan tenaga kerja, yang dari tahun ke tahun menjadi masalah bagi pemerintah dan pencari kerja, khususnya pencari kerja angkatan muda. Pelaku usaha dengan usia yang produktif dengan memiliki pendidikan yang cukup tinggi, diharapkan dapat menerima serta memahami materi yang disampaikan oleh nara sumber dengan lebih baik, sehingga penguasaan literasi akuntansi SAK ETAP dan 
tatakelola keuangan berbasis Android, dapat menambah keunggulan penguasa UMKM untuk berkompetisi, khususnya dalam mengakses permodalan dari perbankan dan lembaga keuangan.

Berdasarkan jenis usaha, sesuai dengan data statistik yang dipublikasikan oleh Pemerintah Kota Bogor tahun 2019, sebagian besar pelaku usaha UMKM di Kota Bogor adalah pelaku usaha industri Kuliner (BPS Kota Bogor, 2019). Hal tersebut tercermin dari jumlah peserta yang mengikuti pelatihan. Kelompok jenis usaha yang terbesar adalah UMKM Kuliner, kemudian disusul oleh kelompok usaha jenis Souvenir dan kemudian jenis industri lainnya. Modal usaha pelaku UMKM dengan nilai terendah lebih dari 5 juta rupiah, sedangkan nilai tertinggi mencapai 500 juta rupiah. Berdasarkan rata-rata, terdapat sekitar $80 \%$ dari pelaku usaha UMKM memiliki modal usaha antara 5 juta sampai dengan 190 juta rupiah.

Sedangkan omset usaha, para pelaku UMKM memiliki omset terendah berkisar 10 juta rupiah sampai dengan 99 juta rupiah, bahkan terdapat dua usaha kuliner yang memiliki omset diatas 100 juta sampai dengan 400 juta rupiah per tahun. Rata-rata keuntungan yang diperoleh berada diatas 4 juta rupiah sampai dengan 12 juta rupiah pertahun. Namun demikian terdapat empat usaha UMKM yang bergerak dibidang kuliner, mendapatkan keuntungan diatas 20 juta sampai dengan 100 juta rupiah per tahun. Hal ini membuktikan bahwa jenis usaha industri UMKM, memiliki prospek yang baik dan menjanjikan, untuk dimasuki oleh angkatan kerja produktif. Dengan demikian, mendorong usaha yang dilakukan oleh UMKM, merupakan sesuatu yang perlu dilakukan oleh pemerintah melalui kerjasama dan sinergi dengan para akademisi. Salah cara yang dapat dilakukan dalam waktu dekat adalah dengan memberikan pelatihan dan pendampingan, secara berkesinambungan dan terpadu guna meningkatkan efisiensi dan kinerja usaha, agar para pelaku UMKM bisa naik kelas, dapat tetap eksis untuk dapat menunjang dan menjadi sebagai salah satu pilar ekonomi nasional, dapat terwujud.

Namun demikian, berdasarkan wawancara dan observasi yang dilakukan terhadap para pelaku usaha UMKM yang ada, cukup memprihatinkan, karena belum satupun peserta UMKM yang ada sudah memiliki pengetahuan dan mengimplementasikan pembukuan SAK ETAP. Begitu juga dengan kemampuan tatakelola keuangan berbasis teknologi digital Android. Karena, melihat modal, omset penjualan dan keuntungan usaha yang mereka dapatkan, seharusnya para pelaku usaha yang ada sudah melakukan pembukuan dan pelaporan keuangan SAK ETAP dengan telah menguasai tatakelola keuangan berbasis teknologi digital Android, karena transaksi penjualan dan pembayaran saat ini sudah bertasformasi dari sistem konvensional ke digital. Hingga saat ini, tatakelola keuangan para pelaku UMKM, masih menggunakan metode tradisional dengan catatan yang sangat sederhana, bahkan ada beberapa pengusaha pelaku UMKM tidak melakukan pencatatan sama sekali, dalam mengelola keuangan usahanya. Untuk itu, pelatihan dan pendampingan terhadap pelaku usaha UMKM khususnya dalam tatakelola keuangan berbasis SAK ETAP dengan teknologi berbasis digital Android, penting untuk dilakukan, guna meningkatkan pengetahuan dan skill mereka.

Observasi yang dilakukan terhadap peserta pelatihan Pengabdian Kepada Masyarakat (PKM) baik melalui tanya jawab secara verbal, maupun melalui kuesioner yang disampaikan. Hampir seluruh peserta menyatakan bahwa, pelatihan yang dilakukan oleh akademisi yang bekerjasama dengan instansi terkait, dalam hal ini Dinas Koperasi dan 
UMKM Kota Bogor, dengan tema "Pelatihan Akuntansi Koperasi dan UMKM Berbasis Entitas Tanpa Akuntabilitas Publik (ETAP) dan Android, bermanfaat baik bagi pelaku usaha UMKM. Dikarenakan pelatihan yang di sampaikan oleh akademisi sebagai narasumber, tepat guna dan tepat sasaran, karena dapat diaplikasikan secara langsung dan berkaitan erat dengan kegiatan usaha mereka sehari-hari. Sehingga manfaat dari pelatihan yang diberikan dapat langsung dirasakan. Hampir seluruh peserta, menyatakan bahwa pelatihan semacam ini sangat bermanfaat dan membantu meningkatkan keterampilan dan pengetahuan dalam tatakelola keuangan pelaku usaha, karena aplikatif dan tanpa harus melakukan investasi berbiaya mahal atas aplikasi dan teknologi yang ditawarkan. Untuk itu para pelaku usaha UMKM yang mengikuti pelatihan, menyarankan, agar pelatihan seperti ini dapat dilakukan secara berkesinambungan dan terprogram dengan baik, guna membantu mereka meningkatkan pengetahuan dan skill tatakelola keuangan dengan baik dan benar, sehingga efisiensi dan kinerja usaha UMKM dapat ditingkatkan dari waktu ke waktu.

\section{SIMPULAN DAN SARAN}

Berdasarkan pembahasan dan uraian di atas, dari kegiatan penelitian dan pengabdian kepada masyarakat tersebut, dapat disimpulkan beberapa hal berikut ini:

1. Sebagian besar pengusaha UMKM belum memiliki pengetahuan dan keterampilan dalam mengimplementasikan pembukuan sesuai standar akuntansi berbasis ETAP, untuk meningkatkan efisiensi dan kinerja usaha mereka, teru tama untuk tatakelola keuangan yang baik dan benar guna mengakses permodalan dari pihak ketiga.

2. Seluruh pelaku UMKM belum memiliki pengetahuan dan keterampilan untuk melakukan tatakelola keuangan berbasis digital, karena biaya in vestasi terhadap teknologi yang mahal dan literasi terhadap tatakelola keuangan digital yang mereka miliki masih sangat rendah.

3. Berdasarkan temuan dilapangan, semua pelaku usaha UMKM yang mengikuti pelathan tatakelola keuangan berbasis SAK ETAP dan teknologi digital Android, merasa sangat terbantu dengan pelatihan yang diberikan oleh Akademisi bekerjasama dengan Dinas Koperasi \& UMKM kota Bogor, karena mendapatkan pengetahuan yang berkualitas dengan zero investasi teknologi, untuk meningkatkan literasi dan pengetahuan mereka dalam tatakelola keuangan.

4. Terbatasnya peserta yang dapat mengikuti kegiatan pelatihan, pendampingan dan penelitian pada kesempatan ini, karena harus dilakukan dengan menjaga protokol kesehatan yang ketat. Para pelaku usaha UMKM dan Koperasi, menyarankan agar pelatihan sejenis dapat dilakukan pelatihan-pelatihan lanjutan. Agar mereka betul-betul dapat mengerti dan menguasai literasi akuntansi SAK ETAP dan teknologi tatakelola keuangan berbasis Android.

5. Berdasarkan manfaat ilmu yang diperoleh, keterampilan yang didapat serta efisiensi investasi teknologi yang dirasakan. Para pelaku usaha UMKM dan Koperasi, menyarankan agar pelatihan-pelatihan serta pendampingan yang dilakukan oleh Akademisi yang bekerjasama dengan instansi terkait, dalam hal ini Dinas Koperasi dan UMKM dapat terus dilanjutkan secara berkesinambungan, terstruktur dan komprehenship dimasa yang akan 
datang. Sebagai salah satu cara untuk meningkatkan keunggulan kompetitif bagi Koperasi dan UMKM agar tetap dapat eksis dalam menghadapi persaingan usaha.

\section{UCAPAN TERIMA KASIH}

Program Pengabdian Kepada Masyarakat ini dapat terselenggara dengan baik berkat dukungan dan fasilitas yang diberikan oleh berbagai pihak, untuk itu kami menyampaikan terimakasih yang sebesar-besamya kepada:

1. Direktur Sekolah Pascasarjana Universitas Pancasila Jakarta

2. Ketua Program Magister Akuntansi - Sekolah Pascasarjana Universitas Pancasila Jakarta

3. Ketua Lembaga Penelitian dan Pengabdian Kepada Masyarakat - Universitas Pancasila Jakarta

4. Dinas Koperasi dan UMKM, Kota Bogor

5. Semua pihak yang tidak dapat kami sebutkan satu per satu, yang telah mendukung pelaksanaan Kegiatan PKM ini, sehingga acara ini dapat terlaksana dengan baik dan lancar.

\section{REFERENSI}

Antaranews.com. (2020a). DPRD Kota Bogor dukung UMKM tetap eksis saat pan demi Covid-19. Retrieved February 24, 2021, from

https://megapolitan.antaranews.com/berita/123548/dprd-kota-bogor-dukung-umkmtetap-eksis-saat-pandemi-covid-19

Antaranews.com. (2020b). Kemenkeu Paparkan Dampak Covid-19 Bagi dayan tahan UMKM. Retrieved February 19, 2021, from

https://www.antaranews.com/berita/1841724/kemenkeu-paparkan-dampak-covid-19bagi-daya-tahan-umkm

BPS Kota Bogor. (2020). Kota Bogor Dalam Angka 2020. Retrieved February 18, 2021 , from https://bogorkota.bps.go.id/publication/2020/04/27/8be591177823581bbbf06bbb/kota -bogor-dalam-angka-2020.html

CnnIndonesia.com. (2020). Setahun Lalu Pasien Pertama Covid-19 ditemukan di Wuhan. Retrieved February 24, 2021, from https://www.cnnindonesia.com/internasional/20201204124554-113-577951/setahunlalu-pasien-pertama-covid-19-ditemukan-di-wuhan

Kompas.com. (2020). Diumumkan Awal Maret, Ahli: Virus Corona Masuk Indonesia dari Januari. Retrieved February 18, 2021, from https://www.kompas.com/sains/read/2020/05/11/130600623/diumumkan-awal-maretahli--virus-corona-masuk-indonesia-dari-januari

PikiranRakyat.com. (2021a). BRI Micro dan SME Index (BMSI) Kuartal IV-2020:

Optimisme Pelaku UMKM di Tengah Tantangan Pemulihan Ekonomi. Retrieved 
February 18, 2021, from https://www.pikiran-rakyat.com/ekonomi/pr-011456086/brimicro-dan-sme-index-bmsi-kuartal-iv-2020-optimisme-pelaku-umkm-di-tengahtantangan-pemulihan-ekonomi

PikiranRakyat.com. (2021b). Digitalisasi UMKM Bantu Pulihkan Perekonomian, Cepat Terealisasi Jika Masyarakat Peduli Kesehatan. Retrieved February 25, 2021, from https://www.pikiran-rakyat.com/nasional/pr-011035025/digitalisasi-umkm-bantupulihkan-perekonomian-cepat-terealisasi-jika-masyarakat-peduli-kesehatan

Sailendra, S., Suratno, S., \& Tampubolon, M. (2020). Tatakelola Keuangan dan Akses Permodalan UMKM Terhadap Perbankan dalam Meningkatkan dan Pengembangan Nilai Ekonomi Usaha: UMKM Pujasera Cempaka Putih Jakarta Pusat. Capacitarea, 1(1), 24-34. Retrieved from http://journal.univpancasila.ac.id/index.php/CAPACITAREA/article/view/1456

Syam, M. A., Djaddang, S., Salim, F., \& Rachbini, W. (2020). Kick Off Peningkatan Potensi Ekonomi Kreatif Masyarakat Melalui Koperasi, Bumdes dan UKMBerbasis Kearifan Lokaldi Kabupaten Soppeng. Capacitarea, 1(1), 1-11. Retrieved from http://journal.univpancasila.ac.id/index.php/CAPACITAREA/article/view/1340 